\title{
Ecological Engineers: Southeastern Pocket Gophers Are One of Nature's Architects ${ }^{1}$
}

\author{
Gabriel J. Miller, Steve A. Johnson, and Lora L. Smith²
}

\section{What is Ecological Engineering?}

Ecological engineering is defined as the creation, modification, and maintenance of environments by plants and animals. All organisms affect their environment in some small way, but ecological engineers make significant changes such as regulating the availability of essential resources (like food, water, and shelter) or altering natural processes (such as water flow). By modifying their habitats, ecological engineers also influence the presence or absence of plants and animals in natural communities. Scientists recognize two types of ecological engineers: autogenic and allogenic.

\section{Autogenic Engineers}

Autogenic engineers provide or modify habitat through their presence or physical structure (these are typically plants). An example of an autogenic engineer is a Live Oak tree (Quercus virginiana, Fig. 1). Environmental conditions beneath the tree's limbs and leaves (i.e., its canopy) are different than conditions outside the tree's canopy. In summer, for example, light levels are typically lower and temperatures are cooler under the protective cover of the canopy than in areas beyond the canopy.

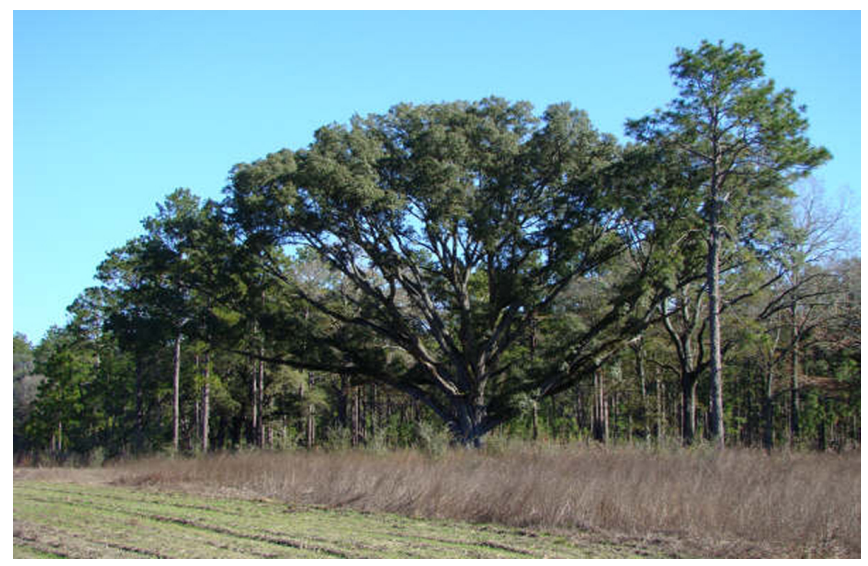

Figure 1. A Live Oak tree (Quercus virginiana) is an example of an autogenic engineer - its presence and physical structure provides and modifies habitat. Credits: Gabriel J. Miller, University of Florida, 2007

Live Oaks also provide cavities, which serve as shelter or nesting sites for various animals. Cavities provide refuge to treefrogs, tree-dwelling lizards and snakes, birds, and smaller mammals like opossums

1. This document is WEC244, of the Department of Wildlife Ecology and Conservation, Institute of Food and Agricultural Sciences, University of Florida. First published April 2008. Please visit the EDIS Web Site at http://edis.ifas.ufl.edu. For a better understanding of figures and graphics, please print in a color printer.

2. Gabriel J. Miller, University of Florida/IFAS, Department of Wildlife Ecology and Conservation, Gainesville, FL

Steve A. Johnson, Ph.D., Assistant Professor, University of Florida/IFAS, Gulf Coast REC and Department of Wildlife Ecology and Conservation, Plant City, FL

Lora L. Smith, Ph.D., Associate Scientist, Joseph W. Jones Ecological Research Center, Newton, GA 
and squirrels. Certain plant species known as epiphytes (plants which grow on other plants), such as Spanish Moss (Tillandsia usneoides) and Resurrection Fern (Polypodium polypodioides), prefer the canopy of Live Oaks as their homes. Live Oaks produce acorns, a favored food of many game animals like deer and turkey. The presence and structure of live oaks provide numerous resources that other plants and animals rely on for their existence.

\section{Allogenic Engineers}

Allogenic engineers alter the environment through their activities. The American Beaver (Castor canadensis) is the traditional example of an allogenic engineer. These industrious mammals use trees and other vegetation to construct dams (Fig. 2). Beaver dams alter streams in several ways; decreasing water flow is the most noteworthy effect. Slow-moving water allows fine soil particles and organic matter (i.e. decaying plants) to settle to the bottom, enriching the water of the beaver pond.

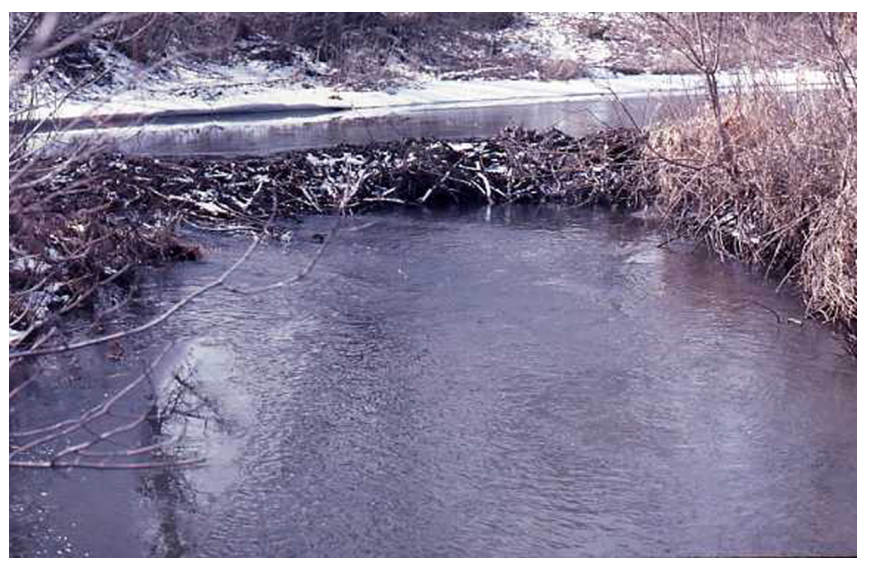

Figure 2. The American Beaver (Castor canadensis) is an example of an allogenic engineer - its dam building activities alter the environment. Credits: Minnesota Department of Natural Resources

Plant and animal communities in and around beaver impoundments change in response to water levels and flow as well as increased nutrients.

Numerous species of animals, such as snakes, turtles, muskrats, and raccoons use beaver dams and dens as feeding and resting sites. Many plants and animals found in association with beaver dams are unable to exist without them. For example, some salamanders and frogs are unable to reproduce in fast-flowing streams and rely on beaver ponds in which to breed.

\section{The Southeastern Pocket Gopher as an Ecological Engineer}

An important allogenic ecological engineer in Florida is the Southeastern Pocket Gopher (Geomys pinetus, Fig. 3), also known as the "sandy-mounder" or "salamander." This rodent is found in southern Alabama, southern Georgia, and all but southern-most Florida (Fig. 4). Pocket Gophers live in dry, sandy uplands where they excavate extensive underground burrow systems. The most notable engineering activities of Pocket Gophers include soil tilling, tunnel construction (as a source of shelter for wildlife), and root herbivory.

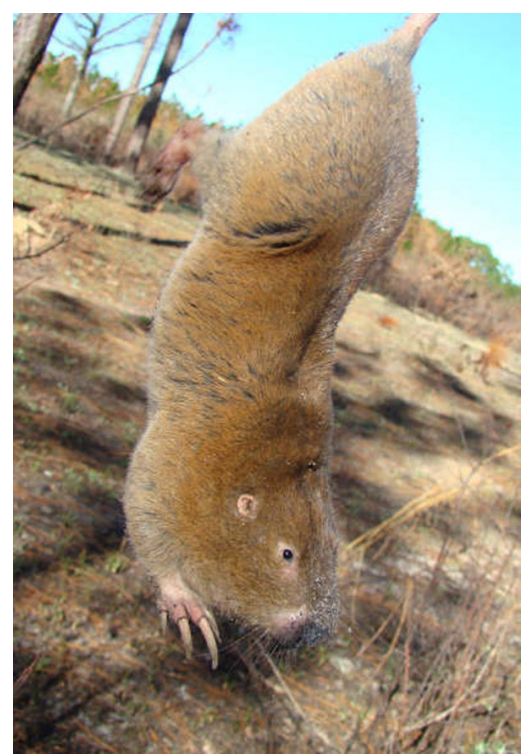

Figure 3. The Southeastern Pocket Gopher (Geomys pinetus) is an important allogenic engineer in Florida. Credits: Gabriel J. Miller, University of Florida, 2007

\section{Soil Tilling}

Probably the most important habitat-altering activity of Pocket Gophers is soil mixing. Typically, soil particles settle into distinct layers or "horizons." When gophers tunnel and build mounds (Fig. 5) they disrupt soil layering, they aerate the soil, and they cycle nutrients. Studies have found that natural areas with gopher activity have better plant productivity and diversity than areas lacking this allogenic engineer. 


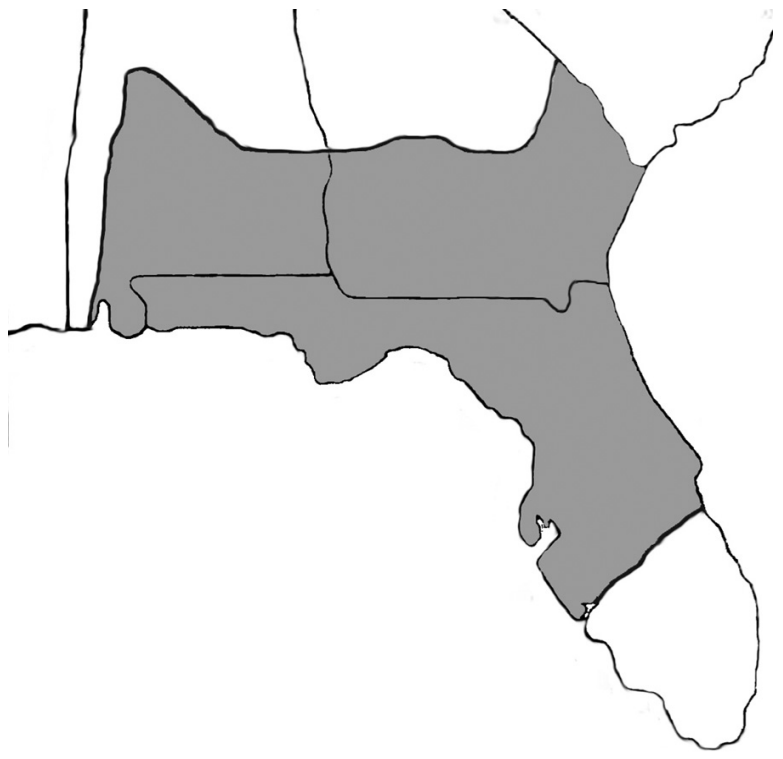

Figure 4. Range of the Southeastern Pocket Gopher (Geomys pinetus). Credits: Monica E. McGarrity, University of Florida, 2008

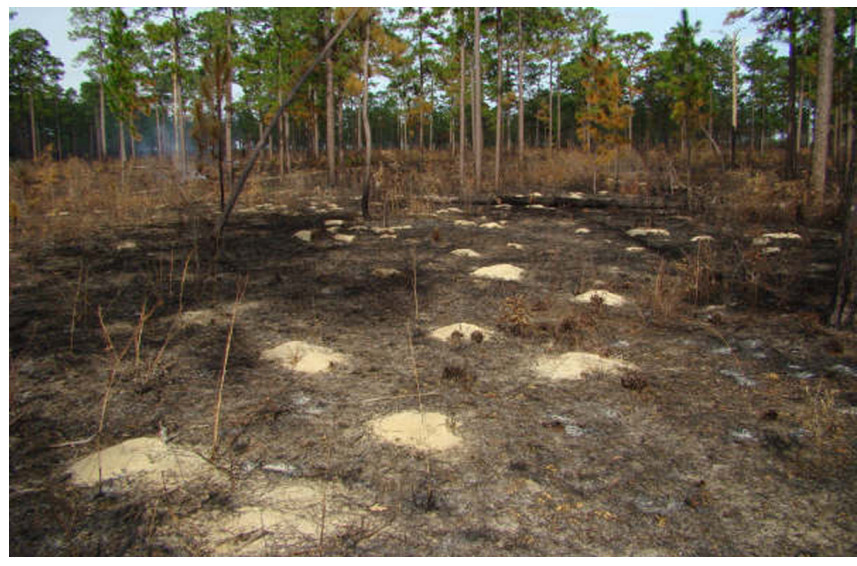

Figure 5. The Southeastern Pocket Gopher (Geomys pinetus) tills the soil by digging tunnels and building mounds -- probably its most important habitat-altering activity. Credits: Gabriel J. Miller, University of Florida, 2007

\section{Tunnels as Shelter}

Pocket gophers are known to excavate extensive tunnel systems (some greater than $500 \mathrm{ft}$. in length). Research suggests that gopher tunnels serve as an important shelter for a variety of animal species. Typical burrow inhabitants include many insects (some are exceptionally rare), salamanders, frogs, lizards, some snakes, and small mammals.

Some species of beetles and camel crickets are very rare and exist only in burrows made by gophers.
These insects have evolved with gophers and are entirely dependent on them for their survival. The Florida Pine Snake (Pituophis melanoleucus mugitus) is a large, impressive snake that shares habitat with the Southeastern Pocket Gopher. Pine snakes spend much of their time underground and prefer to use Pocket Gopher burrows as a place to hide and rest.

\section{Root Herbivory}

By feeding on plant roots, Pocket Gophers can drastically affect the local plant community. Some plants can tolerate root herbivory and even flourish, but others are adversely affected. For example, grasses are known for responding favorably to root herbivory, which may be why gophers and grasses coexist together. Little is known about the effects of root herbivory on most plants, but it is likely that the root herbivory of gophers influences plant communities.

\section{Conservation Issues Affecting Southeastern Pocket Gophers}

The Southeastern Pocket Gopher is reportedly declining in all three states, with the most notable losses in Alabama and Georgia. This decline is mainly due to land development activities of humans. Widespread residential and commercial development, industrial-scale agriculture, and extensive roads and highway systems are all major obstacles to the continued existence of Southeastern Pocket Gophers.

The decline of gophers does not just concern the rodents themselves, but also those species that depend on them as habitat engineers. As gophers decline, populations of rare insects, like camel crickets or scarab beetles, are in danger of becoming extinct. Despite their apparent importance as ecological engineers, gophers have not been offered protection by any state nor by the federal government. Furthermore, many land owners consider Pocket Gophers a nuisance because of their habit of tunneling in yards and golf courses. Despite these concerns, pocket gophers should to be tolerated, especially in their native upland habitats. To ensure survival of the Southeastern Pocket Gopher and the 
many species coexisting with it, tracts of upland pine habitat need to be protected and properly managed.

\section{Additional Resources}

University of Florida Wildlife Extension http://www.wec.ufl.edu/extension

- This site provides information on a variety of wildlife related topics. For gopher information, click on the heading Wildlife Information, then Wildlife Articles and Factsheets, Wildlife by Species, Wildlife A to $Z$, Gophers. Included is a general article about Pocket Gophers and their control, as well as a quick reference sheet.

The Gopher Project

http://www.famu.org/gopher/index.html

- This site, based at Florida A\&M University, explains a project dedicated to the study and conservation of insects dependent on the burrows of Pocket Gophers.

\section{References}

Huntly, N. and R. Inouye. 1988. Pocket gophers in ecosystems: patterns and mechanisms. Bioscience 38:786-793.

Jones, C. G., J. H. Lawton and M. Shachak. 1994. Organisms as ecosystem engineers. Oikos 69:373-386.

Mitsch, W. J. 1998. Ecological Engineering - the 7-year itch. Ecological Engineering 10:119-130.

Reichman, O. J. and E. W. Seabloom. 2002. The role of pocket gophers as subterranean ecosystem engineers. Trends in Ecology and Evolution 17:44-49.

Skelley, P. E. and R. D. Gordon. 2001. Scarab beetles from pocket gopher burrows in the southeastern United States (Coleoptera: Scarabaeidae). Insecta Mundi 15:77-93. 